\title{
Screening of potential sources of tannin and its therapeutic application
}

\author{
Mamta Kumari, ", Shashi Jain ${ }^{2}$ \\ ${ }^{1}$ Polytechnic in Home Science, Junagadh Agricultural University, Keriya Road, Amreli, Gujarat-365601, India \\ ${ }^{2}$ Department of Foods \& Nutrition, College of Home Science, MPUAT, Udaipur, Rajasthan-313001, India
}

\section{Email address:}

mamta.kumari27@gmail.com (Mamta K.)

\section{To cite this article:}

Mamta Kumari, Shashi Jain. Screening of Potential Sources of Tannin and Its Therapeutic Application. International Journal of Nutrition and Food Sciences. Special Issue: Functional Foods and Nutraceuticals for Management of Type 2 Diabetes.

Vol. 4, No. 2-1, 2015, pp. 26-29. doi: 10.11648/j.ijnfs.s.2015040201.15

\begin{abstract}
Tannins are a unique category of plant phytochemicals especially in terms of their vast potential health-benefiting properties. Researchers have described the capacity of tannins to enhance glucose uptake and inhibit adipogenesis, thus being potential drugs for the treatment of non-insulin dependent diabetes mellitus. Thus, the present research was conducted to find out tannin content of food products. The percentage of tannin in various analyzed sources ranged from 0.0 to $108.53 \%$; highest in kathaa and lowest in ker and mango bark. The percentage of tannins present in the plants, however, varies. Numerous studies have confirmed that the naturally occurring polyphenols are key factor for the beneficial effects of the herbal medicines. Isolation and identification of active constituents from plants, preparation of standardized dose \& dosage regimen can play a significant role in improving the hypoglycaemic action.
\end{abstract}

Keywords: Tannins, Diabetes, Polyphenols, Antioxidant, Hypoglycemia

\section{Introduction}

Polyphenols are among a wide variety of active phytochemicals present in human diet. These are naturally occurring compounds found largely in the fruits, vegetables, cereals and beverages [1]. These molecules are secondary metabolites of plants and are generally involved in defense against ultraviolet radiation or aggression by pathogens [2]. In food, polyphenols may contribute to bitterness, astringency, color, flavor, odor and oxidative stability. Almost all polyphenols exhibit antioxidant property and this forms the basis for their purported beneficial health effects associated with conditions such as cancer, cardiovascular diseases, neurodegenerative diseases and aging [3]. Plant tannins, one of the major groups of antioxidant polyphenols found in food and beverages, have attracted a lot of attention in recent years because of their multifunctional properties beneficial to human health. Tannins are thought to interfere in the pathogenesis of degenerative diseases via several mechanisms: antioxidative, antiviral, antitumour, antithrombogenic, and anti-inflammatory. For e.g. certain tannins can selectively inhibit HIV replication [4]. Some monomers also lower blood glucose levels and have insulin- like effects. Tannins are either galloyl esters and their derivatives, in which galloyl moieties or their derivatives are attached to a variety of polyol-, catechin- and triterpenoid cores (gallotannins, ellagitannins and complex tannins), or they are oligomeric and polymeric proanthocyanidins that can possess different interflavanyl coupling and substitution patterns (condensed tannins) [5].

Consumption of tannin-containing food products varies from region to region. It has been reported that tannin consumption in India ranges from 1.5- $2.5 \mathrm{~g} / \mathrm{day}$, depending on the region, and about $1 \mathrm{~g} /$ day within the USA [6]. Though tannin has undesirable effect on the body but in the long term it has beneficial properties also which provide a promising area of research. Thus, the study was conducted to estimate tannin content of some food products found in various regions of India.

\section{Materials and Methods}

\subsection{Sample Selection}

In the present study, the plants having tannin proportion were identified on the basis of available literature. A list of plant sources containing tannin was prepared. Out of those, 
20 sources were selected on the basis of easy and local availability. Selected 20 sources were procured from local vicinity of Udaipur, Rajasthan. Estimation of tannin was performed by titrating the material with standard potassium permanganate solution.

\subsection{Sample Preparation}

$3 \mathrm{~g}$ of the studied food product was extracted with distilled deionised water (dd H2O) into $250 \mathrm{ml}$ volumetric flask during 4 hours at room temperature and then the sample was filtered.

\subsection{Tannin Estimation}

The analyses of tannin content in food products were performed according to the International Pharmacopoeia and AOAC method, after some modifications [7, 8]. $25 \mathrm{ml}$ of infusion were measured into $1 \mathrm{~L}$ conical flask, then $25 \mathrm{ml}$ of indigo solution and $750 \mathrm{ml}$ distill deionised water was added. $0.1 \mathrm{~N}$ aqueous solution of potassium permanganate was used for titration until the blue coloured solution changes to green colour. Then few drops at time until solution becomes golden yellow were added. Standard solution of Indigo carmine is prepared as follows- $6 \mathrm{gm}$ Indigo carmine was dissolved in $500 \mathrm{ml}$ of distill deionised water by heating, after cooling $50 \mathrm{ml}$ of $95-97 \%$ sulphuric acid was added, the solution was diluted to $1 \mathrm{~L}$ and then filtered. The blank tests by titration of a mixture of $25 \mathrm{ml}$ Indigo carmine solution and $750 \mathrm{ml} \mathrm{dd}$ $\mathrm{H}_{2} \mathrm{O}$ were carried out. All samples were analyzed in duplicates.

\subsection{Calculations}

The tannin content ( $\mathrm{T} \%$ ) in the sample is calculated as follows:

$$
\mathrm{T}(\%)=\frac{\left(\mathrm{V}-\mathrm{V}_{0}\right) \times 0.004157 \times 250 \times 100}{\mathrm{~g} \times 25}
$$

where, $\mathrm{V}$ is the volume of $0.1 \mathrm{~N}$ aqueous solution of $\mathrm{KMnO}_{4}$ for the titration of sample, $\mathrm{V}_{0}-$ volume of $0.1 \mathrm{~N}$ aqueous solution of $\mathrm{KMnO}_{4}$ for the titration of blank sample, ml; 0.004157 - tannin equivalent in $1 \mathrm{ml}$ of $0.1 \mathrm{~N}$ Aqueous solution of $\mathrm{KMnO}_{4}$; g-mass of the sample taken for analysis, g; 250 - volume of volumetric flask, ml; 100 - percent, $\%$.

\section{Results and Discussion}

Tannins are polyphenols that are obtained from various parts of different plants belonging to multiple species and found almost in all plants and in all climates all over the world. The percentage of tannins present in the plants, however, varies. Foods have many components other than traditional nutrients, e.g., protein, amino acids, vitamins, minerals, etc., many of which have been associated with biological activities consistent with reduced risk of several chronic diseases and other maladies [9-11]. Numerous studies have confirmed that the naturally occurring polyphenols are key factor for the beneficial effects of the herbal medicines.

Phenolic compounds have described as antihyperglycemic agents in diabetic rats [12]. They have been observed to enhance the glucose uptake through mediators of the insulinsignaling pathways, such as PI3K (Phosphoinositide 3Kinase) and p38 MAPK (Mitogen-Activated Protein Kinase) activation and GLUT-4 translocation [13]. Thus, some of the selected plants were analyzed for their total tannin content and exhibited in Table 1.

Table 1. Total tannin content of analyzed sources.

\begin{tabular}{|c|c|c|c|c|c|}
\hline S. No. & Plant parts used & Common \& Botanical names & Moisture Content & Total Tannin (mg/g) & Dry basis \\
\hline \multirow{13}{*}{1} & \multirow{13}{*}{$\begin{array}{l}\text { Fruit/Pods/ } \\
\text { Galls }\end{array}$} & Majuphal (Quercus infectoria) & 8.42 & 106.24 & 108.6 \\
\hline & & Babul (Acacia Arabica) & 1.58 & 72.74 & 73.9 \\
\hline & & Amla (Emblica officinalis) & 6.33 & 41.57 & 44.37 \\
\hline & & Red Supari (Areca catechu) & 3.51 & 15.24 & 15.79 \\
\hline & & Supari (Areca catechu) & 5.05 & 2.32 & 2.44 \\
\hline & & Dates/ Chuhara (Phoenix sylvestris) & 5.58 & 2.32 & 2.47 \\
\hline & & Munakka (Vitis vinifera) & 0.09 & 2.32 & 2.32 \\
\hline & & Black Pepper/ Kali mirch (Piper nigrum) & 6.68 & 1.14 & 1.22 \\
\hline & & Raisins/ Kismis (Vitis vinifera) & 0.09 & 1.14 & 1.14 \\
\hline & & Harir (Terminalia chebula) & 7.20 & 1.38 & 1.48 \\
\hline & & Badi Ilayachi (Amomum xanthiodes) & 7.96 & 1.38 & 1.49 \\
\hline & & Sangiri (Prosopis cineraria) & 4.02 & 1.38 & 1.43 \\
\hline & & Ker (Cappari deciduas) & 2.88 & 0.0 & 0.0 \\
\hline \multirow{2}{*}{2} & \multirow{2}{*}{ Bark } & Cinnamon/Dalchini (Cinnamomum zeylanicum) & 2.50 & 3.46 & 3.54 \\
\hline & & Mango bark (Mangifera indica) & 3.40 & 0.0 & 0.0 \\
\hline \multirow{2}{*}{3} & \multirow{2}{*}{ Seed } & Mango seeds (Mangifera indica) & 5.89 & 3.46 & 3.67 \\
\hline & & Cumin seeds/ Jeera (Cuminum cyminum) & 4.26 & 2.32 & 2.42 \\
\hline 4 & Heartwood & Kathaa (Acacia catechu) & 12.64 & 108.53 & 124.23 \\
\hline 5 & Root & Turmeric/ Haldi (Curcuma longa) & 6.96 & 1.14 & 1.22 \\
\hline 6 & Gel & Aloe vera/ Guarpatha (Aloe vera) & 7.50 & 1.38 & 1.49 \\
\hline
\end{tabular}

Table 1 shows the plants included in the study listed according to their parts used, common and botanical names and total tannin content in decreasing order with moisture and tannin content on dry matter basis. Different parts of the plants taken for analysis of the tannin content were categorized as fruit/pods, bark, seeds, heartwood, root and 
gel. In general, tannins are more abundant in the parts of the plant that are most «valuable» to it, e.g., new leaves and flowers (which are more likely to be eaten by herbivores) [14-16]. Numerous reports illustrate the effects of environmental and seasonal factors as well as of phonological development. Very briefly, high temperatures, water stress, extreme light intensities and poor soil quality increase the tannin content of plants [17]. Some of these plants and herbs are very commonly consumed in Rajasthan. The frequently used ones include babul, amla, supari, red supari, dates, munakka, raisins, ker, sangiri and mango seeds while some of them are used in daily cooking as spices such as black pepper, badi ilayachi, cinnamon, cumin seeds and turmeric and rest are used as medicinal herbs like majuphal, harir, mango bark, kathaa and aloe vera.

Almost all analyzed sources contain tannins except Ker and Mango bark. The percentage of tannin in various analyzed sources ranged from 0.0 to $108.53 \%$; highest in kathaa and lowest in ker and mango bark. Majuphal (106.24 $\mathrm{mg} / \mathrm{g}$ ), Kathaa (108.53 mg/g), Babul (72.74 mg/g), Amla $(41.57 \mathrm{mg} / \mathrm{g})$ and Red supari $(15.24 \mathrm{mg} / \mathrm{g})$ have been found to be very high in tannin content (Table 1). However, it should be noted that it is difficult to compare the total tannin content with plants found in the literature, this is due to different method of analysis, maturity stage of the plants, the plant cultivars and the plant part used for the analysis [18].

There are various evidences which suggest that the cellular effects of phenolic compounds may be mediated by their interaction with specific proteins that are central to intracellular signalling cascades [29]. In fact, the structure of flavonoids favours their binding to the ATP binding site of a large number of proteins. Previous studies have shown that phenolic compounds can interact such components of signalling pathways as protein kinases [e.g. phosphatidylinositol 3-kinase (PI3K), Akt/PKB, tyrosine kinase C (PKC), and MAP kinases] [20-23]. Therefore, the effect of the flavonoids can be achieved by modulating the phosphorylation state of target molecules (which, among other effects, can result in the modulation of the gene expression) and, in consequence, inhibiting or stimulating pathways/mechanisms that affect the cellular function. Therefore, this modulation can have a beneficial effect on such pathologies as cancer, proliferative diseases and inflammation [24].

The implication of food tannins on human health is a public concern, but it has preventive benefits to health also. They have been considered to be cardio-protective, antiinflammatory, anti-carcinogenic and anti-mutagenic, among others. These protective effects are related to their capacity to: (a) act as free radical scavengers; (b) activate antioxidant enzymes [25]. The protective properties of these compounds mean that it is important to study the principal mechanisms of action of selected polyphenols. Furthermore, advances in this research may lead to the development of nutritional products (i.e. food supplements) and semisynthetic analogs that retain substantial protective capacity but produce minimal adverse side effects.

\section{Conclusion}

Phenolic compounds and flavonoids are a unique category of plant phytochemicals especially in terms of their vast potential health-benefiting properties. Botanical products can improve glucose metabolism and the overall condition of individuals with diabetes not only by hypoglycemic effects but also by improving lipid metabolism, antioxidant status, and capillary function. Taking natural herbs for diabetes treatment can lower blood sugar and reduce the effects of diabetes. Plants hold definite promises in the management of Diabetes mellitus. Isolation and identification of active constituents from these plants, preparation of standardized dose \& dosage regimen can play a significant role in improving the hypoglycaemic action. Herbal supplements for diabetes can be part of a treatment that focuses on nutrition, exercise and monitoring blood glucose levels.

\section{References}

[1] Spencer JP, Abd El Mohsen MM, Minihane AM \& Mathers JC, Biomarkers of the intake of dietary polyphenols: Strengths, limitations and application in nutrition research, $B r J$ Nutr, 99 (2008)12-22.

[2] Beckman $\mathrm{CH}$, Phenolic-storing cells: keys to programmed cell death and periderm formation in wilt disease resistance and in general defence responses in plants, Physiol Mol Plant Pathol 57 (2000) 101-10.

[3] Manach C, Scalbert A, Morand C, Rémésy C \& Jimenez L, Polyphenols: food sources and bioavailability, Am J Clin Nutr 79 (2004) 727-47.

[4] Kashiwada Y, Huang L, Kilkuskie RE, Bodner AJ and Lee KH, Bioorg Med Chem Lett 2 (1992) 235.

[5] Khanbabaee K \& Van Ree T, Tannins: Classification and definition, Nat Prod Rep 18 (2001) 641-649.

[6] Bennick A, Interaction of plant polyphenols with salivary proteins, Crit Rev Oral Biol Med 13 (2002) 184-196.

[7] The international Pharmacopoeia, World Health Organization, $3^{\text {rd }}$ ed., v. 5, Geneva, 2003.

[8] AOAC, Official Method, Spectrophotometric Method, 1965.

[9] Beecher GR, Phytonutrients' role in metabolism: effects on resistance to degenerative processes, Nutr Rev, 9(Part II) (1999) S3-S6.

[10] Hines E, New nutritive substances: beyond the ABCs, Food Quality 6 (1999) 39-43.

[11] Rhodes M \& Price KR, Phytochemicals: classification and occurrence, In: Encyclopedia of Human Nutrition, Academic Press/Harcourt Brace \& Company Publishers New York, NY, 1999, 1539-1549

[12] Pinent M, Blay M, Blade ML, Salvado MJ, Arola L \& Ardevol A, Grape seed derived procyanidins have an antihyperglycemic effect in Streptozotocin induced Diabetic rats and insulinmimetic activity in insulin sensitive cell lines, Endocrinology, 145 (11) (2004) 4985-4990. 
[13] Shimizu M, Kobayashi K, Suzuki M, Satsu H \& Miyamoto Y, Regulation of intestinal glucose transport by tea catechins, Biofactors, 13 (2000) 61-65.

[14] Terril TH, Rowan AM, Douglas GB \& Barry TN, Determination of extractable and bound condensed tannin concentrations in forage plants, protein concentrate meals and cereal grains, J Sci Food Agric 58 (1992) 321-329.

[15] Van Soest PJ, Nutritional ecology of the ruminant, 2nd ed. Cornell Univ Press, Ithaca, NY, USA, 1994, 476

[16] Álvarez Del Pino MC, Frutos P, Hervás G, Gómez A, Giráldez FJ \& Mantecón AR, Efecto del contenido de taninos en la degradación ruminal in vitro de varios órganos de especies arbustivas, ITEA, Prod Anim 22 (2001) 355-357.

[17] Rhoades DF, Evolution of plant chemical defense against herbivores. In: Herbivores: their interactions with secondary plant metabolites (Rosenthal G.A. and Janzen D.H., eds.), Academic Press, NY, USA, 1979, 3-54.

[18] Bravo L, Polyphenols: chemistry, dietary sources, metabolism and nutritional significance, Nutrition Reviews, 56 (1998) 317 333.

[19] Schroeter H, Boyd C, Spencer JP, Williams RJ, Cadenas E \& Rice-Evans C, MAPK signaling in neurodegeneration: influences of flavonoids and of nitric oxide, Neurobiol Aging 23 (2002) 861-880.
[20] Spencer JP, Rice-Evans C \& Williams RJ, Modulation of prosurvival Akt/protein kinase B and ERK1/2 signaling cascades by quercetin and its in vivo metabolites underlie their action on neuronal viability, J Biol Chem, 278 (2003) 34783-34793.

[21] Agullo G, Gamet-Payrastre L, Manenti S, Viala C, Rémésy C, Chap H \& Payrastre B, Relationship between flavonoid structure and inhibition of phosphatidylinositol 3-kinase: a comparison with tyrosine kinase and protein kinase C inhibition, Biochem Pharmacol, 53 (1997) 1649-1657.

[22] Vlahos CJ, Matter WF, Hui KY \& Brown RF, A specific inhibitor of phosphatidylinositol 3-kinase, 2-(4-morpholinyl)8-phenyl-4H-1-benzopyran-4-one (LY294002), J Biol Chem, 269 (1994) 5241-5248.

[23] Gamet-Payrastre L, Manenti S, Gratacap MP, Tulliez J, Chap $\mathrm{H} \&$ Payrastre B, Flavonoids and the inhibition of PKC and PI 3-kinase, Gen Pharmacol, 32 (1999) 279-286.

[24] Williams RJ, Spencer JP \& Rice-Evans C, Flavonoids: antioxidants or signaling molecules, Free Radic Biol Med, 36 (2004) 838-849.

[25] Heim KE, Tagliaferro AR \& Bobilya DJ, Flavonoid antioxidants: chemistry, metabolism and structure-activity relationships, J Nutr Biochem, 13 (2002) 572-584. 